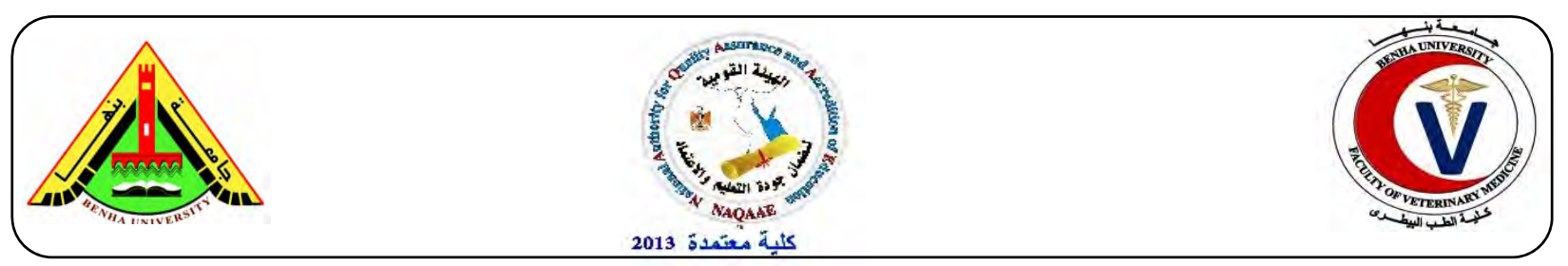

\title{
Bacteriological and molecular studies on staphylococcus aureus isolated from raw milk
}

\author{
${ }^{1}$ Ashraf, A. AbdEL-Tawab, ${ }^{2}$ Nahla, A. Abou El-Roos and ${ }^{2}$ Asmaa, A.M. El-Gendy \\ ${ }^{1}$ Bacteriology, Immunology and Mycology Dep., Fac. Vet. Med. BenhaUniv. ${ }^{2}$ Animal Health Research \\ "Shebin El- Kom branch"
}

\section{A B S T R A C T}

The present study was performed on a total of 100 raw buffalo Milk samples from different sources at El-Menofiya Governorate that the inspected samples were taken in ice box within an a hour for bacteriological examination. The results revealed that 80 out of 100 samples $(80 \%)$ were positive for staphylococcus spp. Out of those 80 samples, $42(53 \%)$ were coagulase positive Staphylococci spp while $38(47 \%)$ were coagulase Negative Staphylococci spp. Out of those 42 coagulase positive Staphylococci spp, 31 were (73.8\%) Staph. aureus. In vitro Gentamycin, Trimethoprim / sulphamethazole, Ampicillin, Cephadrine were the most proper antibiotic against isolated Staph. aureus. By using PCR Spa virulence gene was detected in two studied strains while, enterotoxin E was detected only in one strain out of 6 studied strains. Meanwhile, hIyA and enterotoxin (Sea, Seb, Sec, Sed) virulence genes were not detected in all studied strains.

Keywords: Staphylococcus aureus, raw milk, PCR

\section{INTRODUCTION}

Staphylococci spp. often represent as a part of normal bacterial flora of skin and mucosal surfaces of the respiratory, upper alimentary and urogenital tract of mammals and birds. Thus staphylococci are easily spread between animals and under certain conditions to humans by skin contact with excretions which contain Staphylococci spp., such as saliva, or aerosols released during sneezing and coughing. Moreover, Staphylococci spp. may be spread by animal products such as non-pasteurized milk (Werckenthin et al., 2001). Staphylococcus species are aerobically growing Gram-positive cocci. Isolation of Staphylococcus species is usually not difficult since Staphylococc inot fastidious organism and will grow on commonly media and under variety of conditions (Rowlinson et al., 2006). Staphylococcus aureus is recognized to cause health care associated and community-acquired infections in every region of the world (Yilmaz et al., 2007). It is recognized worldwide as an important food-borne pathogen because of its ability to produce a wide range of extracellular toxin proteins and virulence factors typically resulting in sudden onset of nausea, violent vomiting, abdominal cramps and sometimes diarrhea. (Rosengren et al., 2013). The extracellular protein toxins and virulence factors of Staph.aureus, which are thought to contribute to the pathogenicity of the organism. Staphylococcal enterotoxins (SEs) are serologically grouped into five major classical types, which are SEA, SEB, SEC, SED, and SEE in addition to toxic shock syndrome toxin (TSST -1) which causes toxic shock syndrome in human. SEA and SEB are usually more common in milk and milk products (Chiang et al., 2006). For epidemiological surveillance, the methods most frequently used for the detection of Staphylococcal toxins are 
immune diffusion, agglutination, radioimmunoassay, and enzyme-linked immune sorbent assay. The techniques used to identify toxin genotypes, DNA hybridization and PCR which are very successful and reliable (Johnson et al., 1991). Polymerase chain reaction (PCR) technology is the most promising method due to its rapidity, economical convenience and sensitivity, since it can detect a few microorganisms in clinical samples. Recently, specific oligonucleotide primers for PCR have been described for analysis of Staph. aureus strains for the presence of toxin genes (Johnson et al., 1991 and Becker et al., 1998). Thus, the present study was planned for bacteriological characterization of Staph. aureus isolates from raw milk and detection of virulence genes of the isolated strains using Polymerase chain Reaction.

\section{MATERIAL AND METHODS}

\subsection{Samples}

A total of 100 buffalo's milk samples were collected from small scale shops and individual house hold at Meniofiya Governorate. The samples were transferred in ice box directly with an hour to the laboratory with a minimum delay to be bacteriologically examined.

\subsection{Bacteriological examination}

Milk samples were incubated aerobically at $37^{\circ} \mathrm{C}$ for $24 \mathrm{hr}$ then centrifuged at 3000 rpm for 20 min., the cream and supernatant fluids were discarded. A loopfull from the sediment was streaked into the surface of $7 \%$ salted nutrient agar; baird-parker agar; mannitol salt agar, and milk salted agar. All plates were incubated for 24-48 hours at $37^{\circ} \mathrm{C}$. The developed colonies were picked up and sub cultured for purification. The purified colonies were morphologically identified by Gram stain and biochemical tests(oxidase test, catalase test,coagulase test and V-P test)(Quinn et al., 2002 and Arora, 2003).

\subsection{In-Vitro anti-microbial sensitivity test:}

The isolated Staph. aureus strains were subjected to the sensitivity test against different antibiotics, using the disc and agar diffusion method (Finegold and Martin,1982).

\subsection{Detection of Virulence genes of isolated Staph. aureus by PCR:}

Primers for detection of eight virulence gene that may play a role in virulence of Staph.aureus. These genes were protein A (spa),haemolysin(hlyA) and enterotoxins (sea, seb, sec, sed, see). It was applied on eight random isolated Staph. aureus following QIAamp ${ }^{\circledR}$ DNA Mini Kitinstructions (Catalogue no.M501DP100), Emerald Amp GT PCR mastermix (Takara) with Code No.RR310A and agarose gel electrophoreses(Sambrook et al., 1989).

\section{RESULTS}

Coagulase positive Staph. aureus was identified by morphological and culture characters as well as identical biochemical tests as following:

\subsection{Colonial appearance}

On salted nutrient agar Staph. aureus colonies appear smooth, low convex, glistening and densely opaque after incubation for 24 hours at the optimum growth temperature of $37^{\circ} \mathrm{c}$, while on mannitol salt agar, they were yellow color surrounded by yellow halo with yellow colored medium. On baired Parker medium appear black Small $1 \mathrm{~mm}$ colonies after 24 hours incubation surrounded by an opalescent ring and a clear zone. Pigmentation is characteristic of this species when grown aerobically appear as golden yellow colonies onto milk agar medium

\subsection{Microscopic examination}

Staphylococcus aureus appears as grapes like clusters under light microscope. 


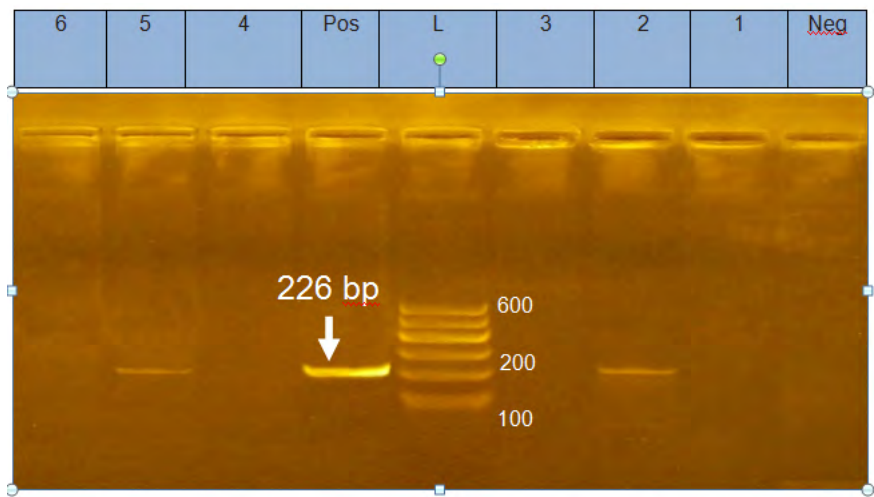

Photo (1): protein A (spa) gene. Lan M: 100-600bp DNA Ladder, Neg: Negative control. Pos: Positive control (at226bp), Lane 1, 3, 4, 6: S. aureus (Negative). Lan 2,5 : S. aureus(Positive).

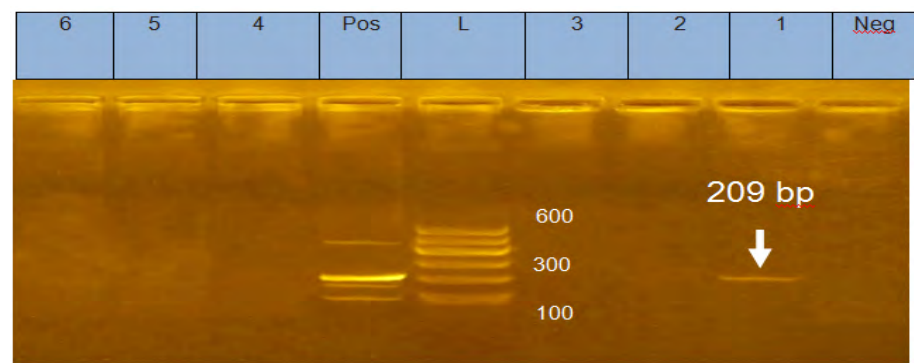

Photo ( 2 ): Enterotoxin e. See gene. Post: positive control (at 209bp). Neg: Negative control. Lane 2, 3, 4, 5, 6: S. aureus (Negative). Lane 1 S. aureus (positive)

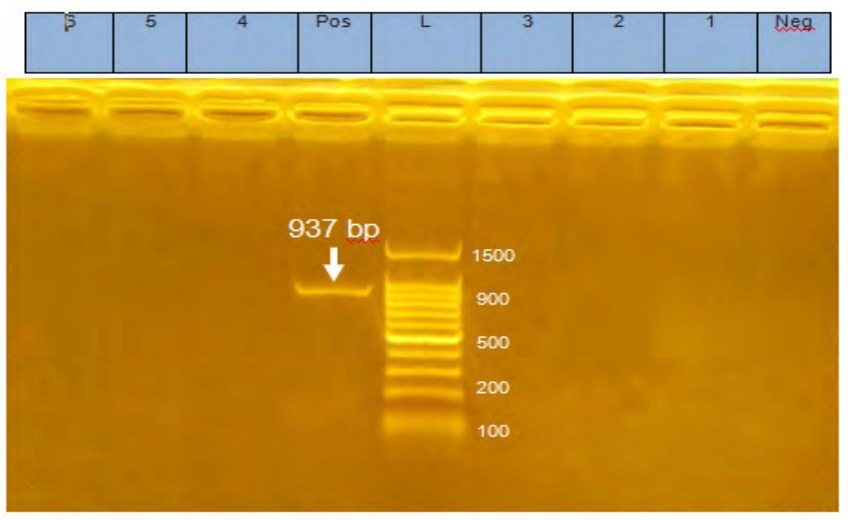

Photo(3): haemolysin (hIy A). Lane M:100-1500bpDNA Ladder. Neg: Negative control. Pos: positive control (at 937 bp. Lane12, 3, 4, 5\& 6 S. aureus (Neg).

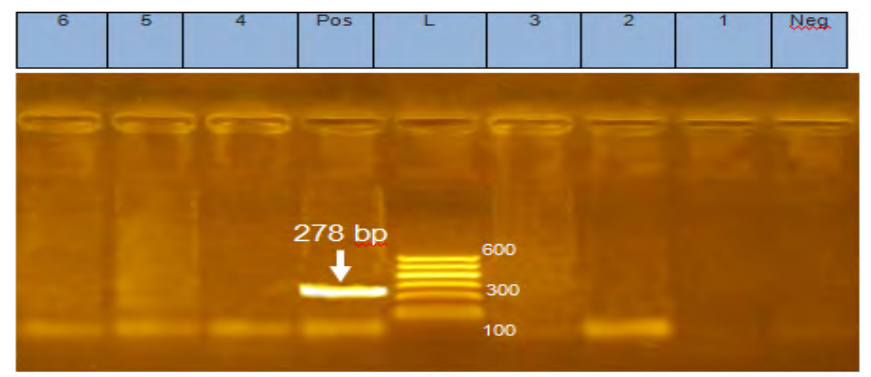

Photo (4) Enterotoxin d. Sed LaneM:100-600bp DNA Ladder. Neg.: Negative control. Pos.: positive control (at 278). Lane1, 2, 3, 4, 5, $6 \mathrm{~S}$. aureus (negative) 
Table (1): Incidence of staphylococci in the examined raw Buffalo Milk:-

\begin{tabular}{ccc}
\hline No. of sample & \multicolumn{2}{c}{ Staphylococcus species } \\
\hline & No. of positive & Percentage \\
& 80 & $80 \%$ \\
\hline
\end{tabular}

Table (2): Catalase Test:-

\begin{tabular}{cc}
\hline No. of samples & Catalase Test \\
\hline 80 & $+\mathrm{ve}$ \\
20 & $-\mathrm{ve}$ \\
\hline
\end{tabular}

Table (3): Result of culture on mannitol salt agar:-

\begin{tabular}{ccc}
\hline No. of positive & $\begin{array}{c}\text { No. of positive } \\
\text { Growth on MSA }\end{array}$ & $\begin{array}{c}\text { No. of mannitol fermenter } \\
\text { isolate }\end{array}$ \\
\hline 80 & 54 & 26 \\
Percentage & $67.8 \%$ & $32.14 \%$ \\
\hline
\end{tabular}

Table (4): Result of pigmentation of positive sample on milk agar:-

\begin{tabular}{ccc}
\hline Pigmentation & No. of positive & Percent \\
\hline Golden yellow & 9 & 11.25 \\
Yellow creamy & 38 & $47.5 \%$ \\
White & 33 & $41.25 \%$ \\
\hline
\end{tabular}

Table (5): Result of Tellurium reduction and lipase activity on Baired Parker Media:-

\begin{tabular}{ccc}
\hline No. of samples & Tellurite reduction & Lipase activity \\
\hline 80 & 80 & 42 \\
Percent & $100 \%$ & $53 \%$ \\
\hline
\end{tabular}

Table (6): Result of the coagulase Test:

\begin{tabular}{ccc}
\hline No. of samples & No. of positive & No. of Negative \\
\hline 80 & 42 & 38 \\
Percent & $53 \%$ & $47 \%$ \\
\hline
\end{tabular}

Table (7): Result of V.P Test to differentiate between S. aureus and other coagulase positive staph as [S. intermdieus, S. hyicus]

\begin{tabular}{ccc}
\hline No. of samples & No. of positive & No. of Negative \\
\hline 42 & 31 & 11 \\
Percent & $73.8 \%$ & $26.19 \%$ \\
\hline
\end{tabular}


Table (8) Result of sensitivity Test:-

\begin{tabular}{ccccccc}
\hline $\begin{array}{c}\text { Antibiotic } \\
\text { disc }\end{array}$ & \multicolumn{2}{c}{ Sensitive } & \multicolumn{2}{c}{ Intermediate } & \multicolumn{2}{c}{ Resistant } \\
\hline SXT & 18 & $58 \%$ & 3 & $9.6 \%$ & 8 & $25.8 \%$ \\
CN & 28 & $90.3 \%$ & 3 & $9.6 \%$ & - & - \\
AM & 18 & $58 \%$ & 7 & $22.5 \%$ & 6 & $19.3 \%$ \\
DA & 9 & $29.03 \%$ & 11 & $35.4 \%$ & 11 & $35.4 \%$ \\
RF & 11 & $35.4 \%$ & 7 & $22.5 \%$ & 13 & $41.9 \%$ \\
CE & 14 & $45.16 \%$ & 4 & $12.9 \%$ & 13 & $41.9 \%$ \\
FL & - & - & 3 & $9.6 \%$ & 28 & $90.3 \%$ \\
AX & 9 & $29.03 \%$ & 11 & $35.4 \%$ & 11 & $35.4 \%$ \\
\hline
\end{tabular}

Table(9): The Results of PCR amplification of different used genes of S. aureus

\begin{tabular}{cccccccc}
\hline \multirow{2}{*}{ sample } & \multirow{2}{*}{ hIg } & Spa & Sea & Seb & Sec & Sed & See \\
\hline 1 & - & - & - & - & - & - & + \\
2 & - & + & - & - & - & - & - \\
3 & - & - & - & - & - & - & - \\
4 & - & - & - & - & - & - & - \\
5 & - & + & - & - & - & - & - \\
6 & - & - & - & - & - & - & - \\
Total NO. & 0 & 2 & 0 & 0 & 0 & 0 & 1 \\
$\%$ & 0.0 & 33.3 & 0.0 & 0.0 & 0.0 & 0.0 & 16.6 \\
\hline
\end{tabular}

\subsection{Biochemical reactions}

Staphylococcus aureus colonies were positive for coagulase, catalase, V-P test and negative oxidase testes. The results revealed that 80 out of 100 raw milk samples $(80 \%)$ were positive for staphylococcus spp. as shown in Table(1). Out of those 80 sample, $42(53 \%)$ were coagulase positive Staphylococci spp. while $38(47 \%)$ were coagulase negative Staphylococci spp. as shown in Table (6). Out of those 42 coagulase positive Staphylococci spp were 31(73.8\%) Staph. aureus. As shown in Table (7). In vitro sensitivity tests in Table (8) showed the isolated Staph. aureus were highly sensitive for Gentamycin, Trimethoprim / Sulphamethazole, Ampicillin, Cephadrine. However, they were resistant to Flumox, Rifamycin, Amoxicillin and Clindamycin. The PCR result detected that spa virulence gene was detected in two strains out of 6 studied strains $(33.3 \%)$ The spa gene was giving product of $226 \mathrm{bp}$ (photo,1), while enterotoxin $\mathrm{E}$ was detected in one strain out of 6 studied strains $(16.6 \%)$ giving product at $209 \mathrm{bp}$ (photo, 2). Moreover, the hIyA gene and enterotoxin (sea, seb, sec, sed) virulence genes were not detected in all studied strain. The hlyA gene was not amplified in Staph.aureus strains and giving no product at $937 \mathrm{bp}$ (photo, 3). The sea gene was not amplified in Staph.aureus strains and giving no product at $102 \mathrm{bp}$ (photo, 2).The seb gene was not amplified in all tested Staph. aureus strains and giving no product at $164 \mathrm{bp}$. The sec gene was not amplified in Staph. Aureus strains only and giving no product at $451 \mathrm{bp}$. The sed gene was not amplified in all Staph. aureus strains and giving no product at 278 bp(photo,4).

\section{DISCUSSION}

Staphylococcus aureus is recognized to cause health care associated and community- acquired infection in every region of the world. (Yilmaz et al., 2007). Enterotoxigenic S.aureus in milk possess a potential health hazard to consumers, the identification of such strain should be used 
as a part of a risk analysis and milk product. (Zouharova \&Rysanek., 2008). Phenotypic assays were by catalase, oxidase, coagulase, tellurite and acetoin production as well as by testing of coagulase positive Staph.aureus against antibiotics while molecular identification performed by detection of S.aureus enterotoxin $\{$ A- B-CD- E $\}$ genes, haemolysin gene and protein A gene. As shown in (Table1) eighty Staphylococci isolates were isolated from 100 milk samples with a percentage of $80 \%$. These nearly similar to those reported by Tsegmed et al., (2007) investigated the occurrence of Staphylococci in raw milk. Staphylococci were isolated from $72(74 \%)$ of the raw 97 raw milk samples. Also Ghaleb et al., (2005) recorded the incidence of staphylococci (68.3\%). And Kamel (1993) isolate staphylococcoi at the rate of (62.8\%) from 320 milk samples. They found that Staph.aureus in $57.5 \%$ on contrary, (Donkor et al., 2007) Cultured 96 raw milk samples and identified Staphylococcus SPP in $14.6 \%$ of samples. In this study, all Staph .aureus isolates were Gram- positive cocci arranged in clusters, they were coagulase producer as coagulase test is the main characteristic and most reliable phenotypic method used for classification of rabbit plasma. These results came paraller with those of Harmon et al., (1991) who reported that Staph. aureus strains were Gram positive cocci.Staphylococcus aureus strains were coagulase positive as recorded by Wladimir et al., (2000) the same result was confirmed by Howard \&Kloss (1993). In this study Staph. aureus gives characteristic blackcentered colonies surrounded by a halo zone onto Baired parker medium as shown in (Table5). In addition, mannitol salt agar is a selective and indicator medium Staph. aureus ferment mannitol form colonies that turn the indicator to yellow color as shown in (Table3). The obtained result was confirmed by Wilson \& Miles (1975) who published that Staph. aureus gives characteristic black-centered colonies surrounded by an area of clearing, sometimes with an area of opacity within onto Baired Parker. Quinn et al (1994) who reported that mannitol salt agar and Baired Parker medium were used and specifically in food microbiology also Colle et al., (1996) and Mackei\&Mccarthey (1996) reported that mannitol salt ager is a selective and indicator medium for Staph. aureus. In this study Staph. aureus represent (31\%) from 80 isolates as shown in (Table7). These results disagree with Rall et al., (2008) who found Staph .aureus in $38(70.4 \%)$ out of 54 raw milk samples and Tenhagen et al.,(2009) who examined milk samples and found that coagulase negative Staphylococci (CNS) were the predominate group of bacteria isolated $(46.8 \%$ of samples) while Staph. aureus could be isolated from (11.7\%) of the examined milk samples, Ateba et al., (2010) examined a total of 28 milk samples were collected and screened for the presence of Staph.aureus and found that all samples were contaminated with Staph.aureus ,OldeRiekerinl et al., (2010) found that the prevalence of Staph.aureus in bulk tank milk was (74\%) and Giannatale et al.,(2011) found that (14.0\%) of 350 examined raw milk samples. Nearly similar result obtained by El-kholy et al.,(1994) who recorded that the incidence reached to (22.9\%). Baudet\&chieze (1994) recorded that the incidence reached to $(30 \%)$ of the examined milk samples, Rampone et al.,(1993) found that Staph. aureus constituted (38.5\%) of the isolates obtained from raw milk samples, Saini et al.,(1994) found that Staph. aureus constituted (34\%) of the isolates, Fabre et al.,(1997)stated that Staph. aureus represent (29\%). Saddek et al., (1999) recorded that the incidence reached to $(29.1 \%)$ of the isolates, Andrade (2001) stated that S.aureus reached to $(30.2 \%)$ and Janosi\&Baltay (2004) recorded that the incidence reached $(32.5 \%)$ of the examined raw milk samples. Higher incidence obtained by Gianneechini et al., (2002) recorded that the incidence reached $(62.8 \%)$. On the other hand, Kivaria et al., (2006) recorded that the incidence of 
S.aureus (6.3\%). Tenhagen et al., (2006) added that S.aureus was present in $(5.7 \%)$ milk samples. The results of in-vitro sensitivity tests for the isolated S.aureus strains are presented in (Table8) revealed that Gentamycin, Trimethoprim, Sulphamethazole, Ampicillin, Cephradine, were sensitive with the highest in-vitro efficiency. Against isolated S.aureus but they were resistant to flummox, Amoxicillin,Rifamycin,

Clindamycin.These results were agreed with that obtained by ( Jha et al., 1994 \& Singh et al., 1994 \& Kamel 1996 \& Andrada et al., 2000 \&Chowdhury et al., 2002). While it was dis-agreed with that recorded by Gentilini et al., (2000) who detected that resistance in $83(40.3 \%)$, 24(11.6\%), 16 (7.7\%) and 7(3.4\%)Staph. aureus isolates for Pencillin, Erythromycin, Pirlimycin and Gentamycin respectively. No resistance was detected for Oxacillin, Cephalothin and Ampicillin sublactam. Also Corti et al., (2003) recorded that (91\%) of the Staph. aureus strains were sensitive to all Antibiotics tested only (9\%) of the strains were resistant to Penicillin $G$ and (7\%) to Amplicillin. So, the present study was directed mainly to recognize some virulence genes that may play a role in virulence of Staph. aureus. By using one of the recent developments molecular biological techniques (PCR). These genes were protein A (Spa) that binds immunoglobulin $\mathrm{G}$ molecules by the FC region in serum, bacteria will bind $\mathrm{IgG}$ molecules with wrong way round by this non-immune mechanism resulting in prevention of opsonization and phagocytosis, haemolysin (hIy A) Which is extracellular, soluble, hydrophilic protein has haemolytic properties and enterotoxin (sea, seb, sec, sed and see) that cause diarrhea and vomiting when ingested and are responsible for staphylococcal food poisoning. The PCR results for Staph. aureus (Table9) showed that protein $\mathrm{A}(\mathrm{Spa})$ was detected in 2 out of 6 studied strains. While enterotoxin $\mathrm{E}$ (see) was detected in 1 out of 6 studied strains. Moreover haemolysin gene was not detected in all studied $S$. aureus strains also enterotoxin (A-B-C-D) were not detected in all studied Staph. aureus strains. These results disagreed with Shin et al., (2002) recorded that most Staph. aureus strains produced enterotoxin B and D.Also Yamashita et al., (2003) detected only Staphylococcal enterotoxin sea gene among se (a- e) genes by PCR in milk samples. Also Lim et al., (2004) detected SEA in 32 isolates, SEB in 3 isolates, SEC in 1 isolate and SEA in 1 isolates. In addition, Adwan et al., (2005) detected sea in 4 strains, seb in 20 strains, sec in 4 strains, sed in 3 strains and see in 3 strains and Peles et al., (2007) detected that toxin genes SEB, SEA and SEC were the most commonly detected whereas none of the isolates possessed the SEE, SHE, SEJ. These results go parallel with Sahekhtiariet al., (2011) detected see only in one isolate.

\section{REFERENCES}

Adwan, G., Abu-Shanab, B., Adwan, K. 2005 .Enterotoxigenic $S$. aureus in raw milk in the north of Palestine. Turk. J. Biol. 9: 229232.

Andrade, M.A. 2001. Subclinical bovine mastitis: Prevalence etiology and sensitivity to antimicrobial drugs test. Ahora Veterinaria, 20(119): 19-26.

Arora, D.R. 2003. Text Book of Microbiology. $2^{\text {nd }}$ Edition (Cultural characteristics of staphylococcus spp(2022013).Publishing by Satish Kumar Jain for CBS publishers.

Ateba, C.N., Mbewe, M., Moneoang, M.S., Bezuidenhout, C.C. 2010. Antibioticresistant S. aureus isolated from milk in the Mafikeng Area North West province South Africa. South African J. of Science, 106(11-12): 1-6.

Baudet, H.M.,Chieze, C. 1994.Investigation into the nature and frequency of bacterial species isolated from cases of subclinical mastitis at drying off. Bulletin Mensuel de la SociétéVétérinaire Pratique défiance, 78(3):129-136.

Becker, K., Roth, R., Peters, G.1998. Rapid and specific detection of toxigenic Staphylococcus aureus: use of two multiplex PCR enzyme immune assays for 
amplification and hybridization of Staphylococcal enterotoxin genes, exfoliative toxin genes, and toxic shock syndrome toxin 1 gene. J. Clin. Micr.36 (9): 2548-2553.

Chiang, Y.C., Chang, L.T., Lin, C.W., Yang, C.Y., Tsen, H.Y. 2006. PCR primers for detection of staphylococcal enterotoxins $\mathrm{K}, \mathrm{L}$ and $\mathrm{M}$; and survey of staphylococcal enterotoxin types in S. aureus isolates from food poisoning cases in Taiwan.J. Food Prot. 69(5): 1072- 1079.

Colle, J.S., Granser, A.G., Marmion, B.P.,Simmons, A. 1996. Practical Medical Microbiology (Mackie and McCartney). Edited by International Student Ed. Of $14^{\text {th }}$ edition. Chapter 11-C. USA. By Churchill Livingstone.

Chowdhury, M., Saha, G.R., Chowdhury, J., Das, S.K. 2002. Subclinical mastitis in crossbred cows. J. of Interacademicia. 6 (Special): 712-715.

Corti,S., Sicher, D., Regli, W., Stephan, R. 2003. Current data on antibiotic resistance of the most important bovine mastitis pathogens in Switzerland. Schweiz Arch Tierheilkd. 145(12): 571-575.

Donkor, E.S., Aning, K.G., Quaya, J. 2007. Bacterial contaminations of informally marketed raw milk in Ghana. Ghana Medical J., 41 (2): 58-61.

El-Kholy, A.M., Hossein, H.I., Thabet, A.R. 1994. Chemical and cytobacteriological studies for the detection of subclinical mastitis. Assiut Vet. Med. J., 30(60): 154164.

Fabre, J.M., Morvan, H., Lebreux, B., Houffschmitt, P., Berthelot, X. 1997. Prevention of bacteria causing mastitis in France.Part2: Subclinical mastitis. Bulletin des G.T.V. 5: 9-15

Finegold, S.M, Martin, S. 1982. Diagnostic Microbiology $6^{\text {th }}$ ed the C.V. Mosby Company, St. Louis Tranto, London. Wi

Ghaleb, A., Dauod, A., Rateb, A., Jamel,A.O. 2005. Prevalence of microorganism associated with intramammary infection in cows and small ruminant in the north of Palestine. J. of the Islamic University of Gaza 13(1): 165-173.

Giannatale, E.D., Prencipe,V., Tonelli, A., Marfoglia, C., Migliorati, G. 2011. Characterization of $S$. aureus strains isolated from food for human consumption. VeterinariaItaliana, 47(2): 165-173.

Gianneechini, R., Concha, C., Rivero, R., Delucci, I., Moreno, L. J. 2002. Occurrence of clinical and subclinical mastitis in dairy herds in the West Littoral Region in Uruguay. Acta Vet Scand., 43(4): 221-230.

Gentilini, E., Denamiel, Liorente, P.,Goldaly, S., Rebuelto, M., DeGregorio, O 2000. Antimicrobial susceptibility $S$. aureus isolated from bovine mastitis in Argentina. J. Dairy Sci. 83(6): 1224-1227.

Harmon, R.J., Langlois,B.E. ,Dellinger, J.D.1991.A simple medium for the vertification of identity of $S$. aureus of bovine origin. J. Dairy Sci., 74(1): 202.

Howard, B.J., Kloss, W.E. 1993. Staphylococci. Chapter 12. In: Clinical and pathogenic Microbiology, $2^{\text {nd }}$ edition. pp. 243-256.

Janosi, S., Baltay, Z. 2004. Correlation among the somatic cell count of individual bulk milk result of the California Mastitis Test and bacteriological status of the udder in dairy cows. Acta. Vet. Hung., 52(2):173183.

Jha, V.C, Thakur, P.P.,Yadau, J.N. 1994. Bacterial species isolated from clinical bovine mastitis and their antibiotic sensitivity patterns. Vet. Rev. Kathmanda. 29(3): 426-430.

Johnson, W.M., Tyler, S.D., Ewan, E.P., Ashton, F.E., Pollard, D.R., Rozee, K.R. 1991. Detection of genes for enterotoxins, exfoliative toxins, and toxic shock syndrome 1 in Staphylococcus aureus by PCR. J. Clin.Microbial., 29(3): 426-430.

Kamel, A.1993. An investigation on the etiology of subclinical mastitis in bovines. M.V.Sc. Thesis (Bacteriology, Immunology and Mycology) Fac. Vet. Med., Cairo University.

Kivaria, F.M., Noordhuizen, J.P., Kapaga, A.M. 2006. Evaluation of the hygienic quality and associated public health hazards of raw milk marketed by smallholder dairy producers in the Dar Es Salaam region Tanzania. Trop. Anim. Health PROD., 38(3): 185-194.

Kivaria, F.M., Noordhuizen, J.P.T.M., Nieien, M. 2006. Interpretation of California mastitis test scores using $S$. aureus culture results for screening of subclinical mastitis in low yielding small holder dairy cows in 
the Dares Salaam region of Tabzania. Population Studies, P.O. Box 9254.

Lim, S.K., Joo, Y.S., Moon, J. S., Lee, A.R., Nam, H.M., Wee, S. H., Koh, H.B.2004. Molecular typing of enterotoxigenic $S$. aureus isolated from bovine mastitis in Korea. J, Vet. Med Sci., 66(5): 581-584.

Mackie, McCartney.1996. Practical Medical Microbiology. International student Ed., of $14^{\text {th }}$ edition, Chapter 11. Distributed in U.S.A. By Churchill Livengtone.

OldeRiekerink ,R.G., Barkema, H.W., Scholl, D.T., Poole, D.E., Kelton D.F .2010.Management practices associated with the bulk-milk prevalence of $S$. aureus in Canadian dairy farms. Prev. Vet. Med., 97(1):20-28.

Omoe, K., Ishikawa, M.,Shimoda,Y., Hu, D.L., Ueda, S., Shinagawa, K. 2002. Detection of seg, she and sei genes in S. aureus isolates from cows with mastitis, and bovine raw milk.J.Clin. Microbiol. 40(3): 857-862.

Peles, F., Wagner, M., Varga, L., Hein, I., Rieck, P., Guster, K., Keresszt, R.P., Kardos, G., Turcs, nyi.I., Beri, B., Szab,A. 2007. Characterization of $S$. aureus strains isolated from bovine milk in Hungary. Int. J. Food Microbiol., 118(2): 186-193.

Quinn, P.J., Cater, M.E., Markey, B.K., Cater, G.R. 2002. Clinical veterinary microbiological Mosby- Year Book Europe Limited. Staphylococcus species. 118-127

Quinn, P.J., Carter M.E., Morkey, B.K.,Carter, G.R. 1994. Clinical Vet Microbiology.Mosby-Yeay-book, Wolf publishing.Spain, London.

Rall, V.L.M., Vieira, F.P., Rall, R., Vieitis, R.L., Fernandes, A., Candeias, J.M.G, Cardoso, K.F.G, Arau'jo, J.P. 2008. PCR detection of staphylococcal enterotoxin genes in S. aureusstrains isolated from raw and pasteurized milk. Veterinary Microbiology, 132: 408-413.

Rampone, H., Bogni, G., Girraudo, J.,Calzolari, A. 1993.Identification of staphylococci from bovine milk in Argentina. ZbI. Bakt., 279(7),:537-543.

Rosengren, A., Lindblad, M., Lindqvist, R. 2013. The effect of undissociated lactic acid on $S$. aureus growth and enterotoxin A production.Int. J. Food Microbiology.162: 159-166.
Rowlinson, M.C., Le Bourgeois, P., Ward, K., Song, Y., Finegold, S.M., Bricker, D.A. 2006. Isolation of a strictly anaerobic strains of Staphylococcus epidermidis. J.Clin. Microbial. 44(3): 857-860.

Saddek, S.R., Abdel-Kader, H.A., AbdelHafeez, M.M. 1999. Bacteriological studies of subclinical mastitis in Friesian cattle in Assiut governorate. Assiut Vet. Med. J., 36-71 (10): 149-162.

Sambrook, J., Fritsch, E.F., Montias, T.1989. Molecular Biology. In: Molecular cloning. Laboratory manual, Second Edition. Cold Spring Harbor Laboratory press, USA.

Saini, S.S., Sharma, J.K., Kwarta, M.S. 1994. Prevalence and etiology of subclinical mastitis among crossbred cows and buffaloes in Punjab. Ind. J. Dairy Sci., 47(2): 103-106.

Sahebekhtiari, N., Nochi, z., Eslampour, M.A., Dabiri, H., Bolfion, M., Taherikalani, M., Khoramian, B., Zali , M.R., Emaneini, M. 2011. Characterization of $S$. aureus strains isolated from raw milk of bovine subclinical mastitis in Tehran and Mashhad. Acta Microbial. Immunol. Hung., 58 (2) :113-121.

Shin, K., Hyon- Pyo, H., Song-Yun, K., Henon, K., Hee-Moo, L. 2002. Molecular typing and detection of enterotoxin by multiplexPCR of $S$. aureus isolated from bovine mastitis. Korean J. Vet. Serv. 25(3): 275283.

Tenhagen, B.A., Koster, G., Wallmann, J. Heuwieser, W. 2006. Prevalence of mastitis pathogens and their resistance against antimicrobial agents in dairy cows in Brandenburg Germany. J. Dairy Sci., 89(7): 2542-2551

Tenhagan, B.A., Hansen, I., Reinecke, A., Heuwieser, W. 2009. Prevalence of pathogens in milk samples of dairy cows with clinical mastitis and in heifers at first parturition. J. Dairy Res., 76(2): 179-187.

Tsegmed, U., Normanno, G., Pringle, M.,Krovacek, K. 2007.Occurance of enterotoxic $S$. aureus in raw milk from cattle in Mongolia. J. Food prot., 70(7): 1726-1729.

Werckenthin, C., Cardoso, M., louismartel, J., Schwarz, S. 2001. Antimicrobial resistance in staphylococci from animals with particular reference to bovine. $S$. hyicus, and Canine S. intermedius. J. Vet. Res., (32): 341-362. 
Wilson, G.S., Miles, A., Parker, M.T. 1983. Topley and Wilson's Principles of Bacteriology, Virology and Immunity. $7^{\text {th }}$ ed., Vol. 2. Systematic Bacteriology, Edward Arnold (publ.) Ltd., pp.:218-245.

Wladimir, P., Da Silva, Maria Teresa, D., Mariza, L., Bernadette, D.G.M. Franco. 2000. Biochemical characteristics of typical and atypical Staphylococcus aureus in mastitic milk and environmental samples of Brazilian dairy farms. Brazilian Journal of Microbiology 31: 103-106

Yamashita, K., Kanazawa, Y., Ueno, M.,Ohta, H., Kitaguchi, M., Kawakami, T., Iwasaki, K., Tsujisawa, E., Morino, Y., Tabita, K. 2003. Significance of the detection of staphylococcal enterotoxin A gene in low fat milk which caused a serious outbreak of food poisoning. Shokuhin EiseigakuZasshi. 44(4): 186-190.

Yilmaz, G.,Aydin, K.,Iskender, S.,Caylan, R.,Koksal, I 2007. Detection and prevalence of inducible clindamycin resistance in staphylococci. J.Med. Microbial., 56(3): 342-345.

Zschock, M., Kloppert, B., Wolter, W., Hamann, H.P., Lammler, Ch.2005. Pattern of enterotoxin genes seg, seh, sei and sej positive $S$. aureus isolated from bovine clinical mastitis.Vet. Microbial. 108(3-4): 243-249.

Zouharova, M., Rysanek, D. 2008. Multiplex PCR and RPLA identification of $S$. aureus enterotoxigenic strains from bulk tank milk. Zoonoses public Health, 55(6): 313319. 